\title{
Pengaruh pemberian ASI eksklusif dengan penurunan berat badan pada ibu postpartum yang menjalankan ibadah puasa selama bulan Ramadhan
}

\author{
Wayan Dane Wijaya*, Aryanti Wardiyah, Lidya Ariyanti \\ Program Studi IImu Keperawatan Universitas Malahayati. *Email : wayandane95@gmail.com
}

\author{
Abstract \\ Effects of breastfeeding on postpartum weight loss among muslim women \\ (Fasting the month of Ramadan)
}

Background: Breast milk is a substantial source of nutrition for the baby. Some Muslim women during Ramadan perform breastfeeding and fasting, although according to Islamic rules for them are optional to exchange for other alternatives form according to religious rules. Base on theory Breastfeeding influences maternal weight loss and pre-survey in Bandar Lampung, interviews with 10 Muslim women, of 7 respondents perform breastfeeding and Ramadan fasting. They said had a decrease of their weight even though is insignificant.

Purpose: To know the effects of breastfeeding on postpartum weight loss among Muslim women (Fasting the month of Ramadan)

Method: A quantitative, analytical survey research design with cross-sectional approach. The population is all post partum at the Sukarame Health Centre, Bandar Lampung. The sample of 142 taken by total sampling. The questionnaire including demographic data and weight scale to measure their weight in the end of Ramadan.

Results : Finding by 142 respondents, $45.8 \%$ respondents perform breastfeeding and $67.5 \%$ respondents Ramadan fasting had a decrease in weight of $39.7 \%$ respondents, with decrease $1-10 \%$ weight. The results of statistical tests using the chi-square test obtained $p$-value $=0.029$ and 0.024 , which means that there is a relationship between breastfeeding, Ramadan fasting and post partum maternal weight loss. It is to be attention in breastfeeding following by sufficient nutrition intake even though Ramadan fasting during breaking the fast (iftar).

\section{Keywords: Breastfeeding; Body weight; Post patum; Muslim women; Fasting the month of Ramadan}

Pendahuluan: ASI merupakan sumber nutrisi penting bagi bayi. Beberapa wanita muslim selama bulan Ramadhan menyusui bayinya dan juga berpuasa, meskipun menurut aturan Islam bagi mereka adalah opsional dapat ditukar dengan bentuk alternatif lain sesuai aturan agama. Berdasarkan teori ada pengaruh menyusui dengan penurunan berat badan, dan pra survei di Bandar Lampung dengan wawancara pada 10 wanita muslim, dari 7 responden yang menyusui dan juga berpuasa di bulan Ramadhan. Mereka mengatakan mengalami penurunan berat badan meski tidak signifikan.

Tujuan: Untuk mengetahui pengaruh pemberian ASI terhadap penurunan berat badan pasca melahirkan pada wanita Muslim yang berpuasa di bulan Ramadhan.

Metode: Penelitian survey analitik kuantitatif dengan desain pendekatan cross-sectional. Populasinya adalah seluruh ibu post partum di Puskesmas Sukarame Bandar Lampung. Sampel sebanyak 142 diambil secara total sampling. Kuesioner tersebut meliputi data demografi dan timbangan untuk mengukur berat badan mereka di akhir bulan Ramadhan.

Hasil : Didapatkan dari 142 responden, 45.8\% responden yang menyusui bayinya dan $67.5 \%$ responden juga menjalankan ibadah puasa Ramadhan mengalami penurunan berat badan sebanyak $39.7 \%$ responden, dengan penurunan berat badan 1-10\% dari berat berat awal kelahiran. Hasil uji statistik dengan menggunakan uji chisquare didapatkan $p$-value $=0.029$ dan 0.024 yang berarti ada hubungan antara pemberian ASI, berpuasa di bulan Ramadhan dengan penurunan berat badan. Disarankan dan diperhatikan dalam menyusui bayinya harus diikuti dengan asupan gizi yang cukup saat buka puasa di bulan Ramadhan.

Kata Kunci : Pemberian ASI eksklusif; Penurunan berat badan; Post partum; Ibadah puasa; Bulan Ramadhan 
Pengaruh pemberian ASl eksklusif dengan penurunan berat badan pada ibu postpartum yang menjalankan ibadah puasa selama bulan Ramadhan

\section{PENDAHULUAN}

Secara nasional, cakupan bayi mendapat ASI eksklusif sebesar $61,33 \%$. Angka tersebut sudah melampaui target RENSTRA tahun 2019 yaitu $44 \%$. Persentase tertinggi cakupan pemberian ASI eksklusif terdapat pada Nusa Tenggara Barat $(87,35 \%)$, sedangkan persentase terendah terdapat pada Papua (15,32\%)(Kementrian kesehatan Republik lindonesia, 2017).

Cakupan bayi mendapat ASI eksklusif tahun 2018 yaitu sebesar $68,74 \%$. Angka tersebut sudah melampaui target Renstra tahun 2018 yaitu $47 \%$. Persentase tertinggi cakupan pemberian ASI eksklusif terdapat pada Provinsi Jawa Barat $(90,79 \%)$, sedangkan persentase terendah terdapat di Provinsi Gorontalo (30,71\%). Sebanyak enam provinsi belum mencapai target Renstra tahun 2018, Sedangkan Provinsi Lampung berada pada urutan ke 11 dengan persesntase $(61,0 \%)$, hal ini mengalami penurunan dari tahun 2017 yaitu pencapaian persentase (64.98\%) (Kementrian Kesehatan Republik Indonesia, 2019).

Data keberhasilan ASI eksklusif di Kota Bandar Lampung dengan membandingkan 5 Puskesmas tertinggi cakupan ASI eksklusif sebesar 100\%, yaitu Wilayah Kerja Puskesmas Sumur Batu dengan persentase $100 \%$, Wilayah Kerja Puskesmas Kebon Jahe dengan persentase $100 \%$, Wilayah Kerja Puskesmas Sukarame dengan persentase 100\%, Wilayah Kerja Puskesmas Korpri dengan persentase 100\%, Wilayah Kerja Puskesmas Sukabumi dengan persentase 100\% (Dinas kesehatan Kota Bandar Lampung, 2019).

Tujuan dari pembangunan kesehatan salah satunya adalah menurunkan angka kematian bayi. Angka Kematian Bayi menurut Sustainanble Depelovment Goals (SDGs) tahun 2015 berjumlah 40 per 1000 kelahiran hidup dan masih menempati peringkat ke-4 tertinggi kematian bayi se-ASEAN. Angka kematian bayi (AKB) adalah jumlah kematian bayi dalam usia 28 hari pertama kehidupan per 1.000 kelahiran hidup (Kementrian Kesehatan Republik lindonesia, 2015).

Manfaat ASI bagi bayi antara lain adalah melindungi bayi dari berbagai macam penyakit karena ASI mengandung antibodi, kandungan ASI dapat membantu perkembangan sistem syaraf otak dan dapat meningkatkan kecerdasan bayi.
Sedangkan manfaat ASI bagi ibu adalah mengurangi perdarahan setelah melahirkan, menjarangkan kehamilan, mengurangi resiko kanker payudara, lebih ekonomis dan murah, mendekatkan hubungan ibu dengan anak, kepuasan emosional dan membagi kasih sayang serta menolong rahim mengerut lebih cepat dan mencapai ukuran normalnya dalam waktu singkat (Kementrian Kesehatan Republik Indonesia, 2015).

ASI selain meningkatkan kekebalan tubuh pada bayi, juga memberi dampak pada ibu bayi yaitu mengalami penurunan berat badan. Menyusui membutuhkan banyak energi sehingga perlunya membantu ibu menyusui kembali ke berat badan normal melalui asupan nutrisi yang memadai (Harsanti, \& Kusumastuti, 2013). Hasil penelitian sebelumnya menunjukkan bahwa selama 6 minggu postpartum, menyusui secara eksklusif berpengaruh terhadap penurunan berat badan ibu selama 6 minggu postpartum, yaitu sebesar 12,9\% dengan rerata penurunan berat badan sebesar $2,08 \mathrm{~kg}$ pada ibu menyusui eksklusif (Puspitaningrum, 2013). Beberapa bukti menunjukan hubungan yang signifikan antara menyusui dengan retensi berat badan postpartum, yaitu dengan menyusui secara penuh berat badan ibu akan turun sebesar 2,57 kg (Padmawati \& Dasuki, 2011).

Berdasarkan hasil pra survey di Puskesmas Sukarame pada tanggal 25 Februari tahun 2020, dengan melakukan wawancara terhadap 10 ibu menyusui, didapatkan 7 orang yang memeberikan ASI eksklusif dan juga menjalankan ibadah puasa di bulan Ramadhan dan mengaku mengalami penurunan berat badannya walaupun hanya $5 \%$ dari berat badan setelah melahirkan.

\section{METODE PENELITIAN}

Penelitian kuantitatif dengan rancangan penelitian Survei Analitik dan pendekatan cross sectional. Populasinya adalah seluruh ibu post partum di Puskesmas Sukarame Bandar Lampung Tahun 2020 dengan sampel 142 menggunakan metode total sampling. Penelitian dilakukan diakhir bulan Ramadhan 2020 dan mendapatkan uji kelayakan etik dengan NO surat 1004/EC/KEPUNMAL/VII/2020 dari komisi etik Universitas Malahayati. Alat ukur yang digunakan dalam 
Pengaruh pemberian ASl eksklusif dengan penurunan berat badan pada ibu postpartum yang menjalankan ibadah puasa selama bulan Ramadhan

penelitian ini berupa hasil kuisoner seperti variabel pemberian ASI Eksklusif, $0=$ jika menyusui penuh selama 0-6 dan 1 = tidak menyusui penuh selama $0-6$ bulan. Variabel lainnya yaitu ikut menjalankan ibadah puasa $0=$ jika berpuasa penuh selama 1 bulan dan 1 = tidak berpuasa penuh selama 1 bulan. Pengukuran berat badan dilakukan setelah bulan Ramadhan dan dibandingkan dengan berat badan 6 bulan sebelumnya. Penggolahan data menggunakan SPSS 13.Uji analisis yang digunakan adalah uji-square.Analisis Odds Ratio (OR) digunakan untuk menetapkan besarnya resiko terjadinya efek pada kasus tersebut.Analisa data menggunakan univariat dan analisa bivariat.

\section{HASIL}

Tabel 1. Karakteristik Demografi Responden ( $N=142$ )

\begin{tabular}{|c|c|c|c|c|c|c|}
\hline Demografi & & $n$ & $\%$ & MS $\pm S D$ & $p$-value & $\begin{array}{c}\text { OR } \\
\text { (CI 95\%) }\end{array}$ \\
\hline $\begin{array}{l}\text { Umur } \\
\text { (Tahun)(Rentang } \\
20-35 \text { ) }\end{array}$ & & 142 & 100 & $26.325 \pm 2.365$ & & \\
\hline Pendidikan & $\begin{array}{l}\text { Rendah } \\
\text { Tinggi }\end{array}$ & $\begin{array}{l}75 \\
67\end{array}$ & $\begin{array}{l}52.8 \\
47.2\end{array}$ & & & \\
\hline Pekerjaan & $\begin{array}{l}\text { IRT } \\
\text { Wiraswasta } \\
\text { PNS } \\
\text { Buruh }\end{array}$ & $\begin{array}{c}56 \\
50 \\
28 \\
8\end{array}$ & $\begin{array}{c}39.4 \\
35.2 \\
19.7 \\
5.7\end{array}$ & & & \\
\hline $\begin{array}{l}\text { Status Berat- } \\
\text { badan }\end{array}$ & $\begin{array}{l}\text { Menurun } \\
\text { Meningkat }\end{array}$ & $\begin{array}{l}55 \\
87\end{array}$ & $\begin{array}{l}39.7 \\
61.3\end{array}$ & & & \\
\hline \multicolumn{7}{|c|}{ Pengaruh Menyusui Dengan Penurunan Berat Badan } \\
\hline $\begin{array}{l}\text { Memberikan ASI } \\
\text { Eksklusif } \\
\text { Selama } 6 \text { bulan }\end{array}$ & $\begin{array}{l}\text { ya } \\
\text { Tidak }\end{array}$ & $\begin{array}{l}65 \\
77\end{array}$ & $\begin{array}{l}45.8 \\
54.2\end{array}$ & & 0.029 & $15(1.32-169.87)$ \\
\hline $\begin{array}{l}\text { Menjalan ibadah } \\
\text { puasa } 1 \text { bulan } \\
\text { penuh selama } \\
\text { bulan Ramadhan }\end{array}$ & $\begin{array}{l}\text { Ya } \\
\text { Tidak }\end{array}$ & $\begin{array}{l}96 \\
46\end{array}$ & $\begin{array}{l}67.6 \\
32.4\end{array}$ & & 0.024 & $10(1.02-103.47)$ \\
\hline
\end{tabular}

Berdasarkan tabel diatas responden berusia antara 20 - 35 tahun dengan mean 26.325 dan Standar Deviation 2.365. Mayoritas berpendidikan rendah sejumlah $52.8 \%$, Pekerjaan sebagai IRT sejumlah $39.4 \%$, dan wiraswasta 35.2\%. Pada Ibu menyusui dengan ASI Ekslusif selama 6 bulan penuh sejumlah 45.8\%, berpuasa sebulan penuh dibulan Ramadhan $67.6 \%$. adanya penurunan berat badan responden sejumlah $39.7 \%$. Hasil uji statistik dengan menggunakan uji chi-square didapatkan p-value $=0.029$ (pemberian ASI) dan 0.024 berpuasa di bulan Ramadhan yang berarti ada hubungan antara pemberian ASI, berpuasa di bulan Ramadhan dengan penurunan berat badan. 


\section{PEMBAHASAN}

Sejalan dengan teori berat badan postpartum (masa nifas atau menyusui) merupakan kombinasi dari berat badan saat hamil dan selisih antara berat badan antara hamil dengan berat badan postpartum (Janney, Zhang, \& Sowers, 1997; Aswita, 2017). Penambahan berat badan postpartum dilakukan dengan mempertimbangkan indeks masa tubuh (IMT) sebelum hamil dan pada masa postpartum dan penambahan berat badan postpartum akan lebih banyak mengalami penurunan bila IMT wanita pada masa hamil lebih tinggi (Baker, Gamborg, Heitmann, Lissner, Sørensen, \& Rasmussen, 2008; Sipasulta, Afiyanti \& Sabri, 2010).

Sejalan dengan penelitian sebelumnya diketahui bahwa terdapat perbedaan penurunan berat badan antara ibu yang menyusui secara eksklusif dan tidak eksklusif, hasilnya juga menunjukkan bahwa selama 6 minggu postpartum, menyusui secara eksklusif berpengaruh terhadap penurunan berat badan ibu selama 6 minggu postpartum, yaitu sebesar $12,9 \%$ dengan rerata penurunan berat badan sebesar 2,08 $\mathrm{kg}$ pada ibu menyusui eksklusif (Margawati, 2010; Sayekti, 2007). Setelah melahirkan ibu akan mengalami kehilangan berat badan selama hamil sekitar 5-6 $\mathrm{kg}$ akibat pengeluaran bayi, plasenta, air ketuban dan darah (Wilda,Sarlis \& Mahera (2018). Pada saat ini terjadi penurunan berat badan sebanyak 2$3 \mathrm{~kg}$ melalui diuresis, pengeluaran lokia dan involusi uteri. Tetapi ada sebagian ibu yang masih mengalami kelebihan berat badan sekitar 1,4-2 kg. Penelitian menunjukkan setelah melahirkan, ibu akan mengalami perubahan atau penurunan berat badan antara 5-11 kg disebabkan proses kelahiran dan memberikan bayinya ASI eksklusif (Kristiyanti, 2013).

Distribusi penurunan BB ibu menyusui dari 142 responden, 55 responden $(55,0 \%)$ mengalami Penurunan BB, 87 responden $(45,0 \%)$ dengan mengalami peningkatan $\mathrm{BB}$. Sejalan dengan teori bahwa ASI Eksklusif adalah pemberian hanya ASI saja selama enam bulan tanpa tambahan cairan apapun, seperti susu formula, jeruk, madu, air teh, air putih dan tanpa pemberian makanan tambahan lain, seperti pisang, bubur susu, biskuit, bubur atau nasi tim. Setelah bayi berusia enam bulan, barulah bayi diberikan makanan pendamping ASI dengan ASI tetap diberikan sampai usia bayi 2 tahun atau lebih. ASI Eksklusif adalah pemberian ASI selama 6 bulan tanpa pemberian minuman atau makanan apapun, termasuk air bening, vitamin dan obat (Banggo, 2017; Maryunani, 2015).
Sejalan dengan penelitian sebelumnya di wilayah kerja Puskesmas Kartasura Sukoharjo. Hasil penelitian menunjukkan berat badan ibu postpartum secara keseluruhan, yang mengalami penurunan berat badan adalah $69,0 \%$ dan yang tidak mengalami penurunan berat badan adalah $31,0 \%$. Status pemberian ASI Pre-Laktal adalah $35,7 \%$, ASI dan susu formula adalah $35,7 \%$ serta susu formula adalah 28,6\%. Hasil uji beda pemberian ASI, ASI dan susu formula serta susu formula menunjukkan tidak ada perbedaan penurunan berat badan dengan $p=0,12$. (Agustina \& Nawangsih, 2017; Puspitaningrum, 2013).

Menurut peneliti, penurunan berat badan dikarenakan kegiatan menyusui yang memerlukan energi besar, saat terjaga, dan proses pembuatan ASI yang ditentukan oleh konsumsi makanan setiap hari.( Amir, \& Sulastri, (2019)Pernyataan diatas sesuai dengan teori menyusui dapat membantu dalam menurunkan berat badannya dikarenakan produksi ASI membutuhkan energi cukup besar (sekitar 500-650 kkal/hari), pemberian ASI dapat membantu mengurangi tumpukan lemak yang terjadi selama kehamilan. Energi yang diperlukan untuk menghasilkan $100 \mathrm{cc}$ ASI sebesar 80-90 kkal.Simpanan lemak selama hamil memasok energi sebanyak 100-200 kkal/hari.Sehingga, untuk menghasilkan $850 \mathrm{cc}$ ASI diperlukan energi sekitar 750 kkal.( Harsanti,\& Kusumastuti, (2013.) Penambahan energi selama menyusui rata-rata hanya 500 kkal/hari. Kekurangan 250 kkal diambil dari cadangan lemak selama hamil. Kebutuhan gizi ibu yang tidak terpenuhi akan diambil dari cadangan lemak sehingga dapat membantu untuk penurunan berat badan.

\section{Menyusui}

Responden dengan menyusui ASI eksklusif sebanyak 71 responden $(70.4 \%)$ dengan $B B$ menurun sebanyak 48 responden $(33.8 \%)$, BB meningkat sebanyak 52 responden $(36.6 \%)$, dan menyusui ASI tidak eksklusif sebanyak 42 responden $(29.6 \%)$, dengan $\mathrm{BB}$ menurun 23 responden (16.2\%), dan BB meningkat sebanyak 19 responden (13.4\%)

Hasil uji statistik menggunakan uji chi square didapat nilai $p$-value $=0.029(<0.05)$ yang artinya terdapat hubungan menyusui dengan penurunan berat badan ibu post partum di Wilayah Kerka Puskesmas Sukarame Bandar Lampung Tahun 2020, dengan nilai $O R=2,277 y a n g$ artinya responden yang memberikan asi tidak eksklusif 2 kali beresiko mengalami peningkatan $\mathrm{BB}$. 
Pengaruh pemberian ASl eksklusif dengan penurunan berat badan pada ibu postpartum yang menjalankan ibadah puasa selama bulan Ramadhan

Sejalan dengan teori bahwa lbu yang menyusui ekslusif ternyata lebih mudah dan lebih cepat kembali ke berat badan semula seperti sebelum hamil pada saat hamil, badan bertambah berat, selain ada janin, juga karena penimbunan lemak pada tubuh, cadangan lemak inisebetulnya disiapka sebagai sumber tenaga dalam produksi ASI (Puswati, 2012).

Pengaruh Menyusui Terhadap Perubahan Berat Badan Ibu Post Partum Di Wilayah Kerja Puskesmas Sawit Kabupaten Boyolali.Hasil penelitan menunjukkan perubahan berat badan ibu post partum yang menyusui secara eksklusif dengna uji paired sample test diperoleh nilai rhitung 2,192 $p=0,049(p<0,05)$.

Dalam penelitian ini ibu yang memberikan ASI eksklusif sebanyak 65 responden $(45,8 \%)$ dan mengalami penurunan $\mathrm{BB}$ menurun sebanyak 32 responden $(22.5 \%)$, BB meningkat sebanyak 33 responden $(23,2 \%)$ hasil penelitian ini menunjukan tidak ada perbedaan antara penurunan dan peningkatan berat badan pada ibu yang memberikan ASI eksklusif, hal ini dapat disebabkan karena faktor pekerjaan ibu rumah tangga yang tidak memiliki kesibukan diluar rumah, akan tetapi ibu juga memiliki jenis pekerjaan yang berbeda-beda, Bayi yang membutuhkan ASI setidaknya 2 jam sekali akan mempengaruhi kondisi tubuh responden. Responden akan lebih cepat merasa lapar, meskipun responden memenuhi kebutuhan dengan makan, namun frekuensi pemberian ASI yang lebih cepat dari pada proses metabolisme makanan untuk kebutuhan ASI pada akhirnya ibu akan mempengaruhi berat badan ibu. Selain itu terdapat dua hormon yang dapat mempengaruhi berat badan ibu yang menyusui yaitu hormon prolaktin dan oksitosin, kedua hormon ini bersumber dari perangsanngan putting susu akibat isapan bayi (Astuti,Ambarwati \& Kartinah, 2013).

Sedangkan menyusui ASI tidak eksklusif sebanyak 42 responden $(29.6 \%)$, dengan $\mathrm{BB}$ menurun 23 responden (16.2\%), dan BB meningkat sebanyak 19 responden (13.4\%) yang tidak melakukan ASI eksklusif dikarenakan ibu sebagian besar memiliki pekerjaan wiraswasta, sedangkan pada ibu yang mengalami peningkatan berat badan, dapat dikarenakan penggunaan KB hormonal yang dapat meningkatkan berat badan ibu (Nugroho, 2011).

Ibu yang memberikan ASI secara Eksklusif akan lebih cepat mengalami penurunan berat badan, hal ini disebabkan karena ibu yang mengalami kekurangan $250 \mathrm{kkal}$ akan diambil dari cadangan kalori wanita yaitu simpanan lemak selama hamil. Hal ini berarti ibu menyusui selama empat bulan akan kehilangan $250 \times 30 \times 4$ kkal = $45.000 \mathrm{kkal}$ yang setara dengan $5 \mathrm{~kg}$ lemak. Hal ini berkebalikan dengan temuan yang dipublikasikan oleh "The International Breastfeeding Journal" yang menyebutkan, selama 4 minggu pertama setelah melahirkan, ibu yang menggabungkan ASI dengan susu formula mengalami penurunanberat badan yang lebih banyak dibanding ibu yang memberikan ASI eksklusif.

Menurut asumsi peneliti, adanya hubungan antara pemberian ASI Eksklusif dengan penurunan berat badan didasari oleh sebagian responden tidak memberikan ASI secara Eksklusif pada bayinya sehingga hal ini mempengaruhi berat badan responden, karena energi sebesar 80-90 kkal diperlukan untuk menghasilkan $100 \mathrm{cc}$ ASI. Simpanan lemak selama hamil dapat memasok energi sebanyak 100-200 kkal per hari. Jadi jika ibu tidak memberikan ASI maka akan terjadi penimbunan lemak yang dapat meningkatkan berat badan. Selain itu dari hasil penelitian diperoleh sebagian ibu tidak memberikan ASI secara Eksklusif pada bayinya namun mengalami penurunan berat badan,hal ini disebabkan oleh faktor lain yaitu ibu mengikuti kegiatan olahraga setiap hari seperti erobik, senam ataupun aktivitas fisik sehingga berat badan ibu mengalami penurunan.

\section{SIMPULAN}

Menyusui ASI eksklusif dapat berpengaruh pada menurunan berat badan begitu juga dengan berpuasa di bulan Ramadhan. Hasil uji statistik menggunakan uji chi square didapat nilai $p$-value < 0.05 ) yang artinya terdapat hubungan menyusui, berpuasa selama bulan Ramadhan dengan penurunan berat badan ibu post partum

\section{SARAN}

Hasil penelitian ini nantinya dapat menambah literatur tentang ASI eksklusif dengan penurunan berat badan ibu menyusui. Perlunya promosi pada para ibu yang masih memberikan ASI eksklusif dan berpuasa si bulan Ramadhan untuk selalu memperhatikan asupan nutrisinya baik saat 
Pengaruh pemberian ASl eksklusif dengan penurunan berat badan pada ibu postpartum yang menjalankan ibadah puasa selama bulan Ramadhan

berbuka puasa, sehingga terpenuhinya nutrisi dan menghasilkan kwalitas ASI yang diharapkan bayinya serta tetap terjaganya imunitas ibu dari penyakit dan penurunan berat badan.

\section{DAFTAR PUSTAKA}

Agustina, E., \& Nawangsih, U. H. E. (2017). Perbedaan berat badan bayi usia 6 bulan antara yang diberi asi eksklusif dan asi tidak eksklusif di kelurahan bumijo wilayah kerja puskesmas Jetis Yogyakarta (Doctoral dissertation, STIKES'Aisyiyah Yogyakarta).

Amir, A. Y., \& Sulastri, D. (2019). Hubungan kadar magnesium dalam asi dan asupan energi ibu dengan penambahan berat badan bayi usia 0-6 bulan di Puskesmas Lubuk Buaya Padang. Jurnal IImu Keperawatan dan Kebidanan, 10(1), 41-48.

Astuti, H. N. T., Ambarwati, W. N., \& Kartinah. K. (2013). Pengaruh menyusui terhadap perubahan berat badan ibu post partum di wilayah kerja Puskesmas Sawit Kabupaten Boyolali (Doctoral dissertation, Universitas Muhammadiyah Surakarta).

Baker, J. L., Gamborg, M., Heitmann, B. L., Lissner, L., Sørensen, T. I., \& Rasmussen, K. M. (2008). Breastfeeding reduces postpartum weight retention. The American journal of clinical nutrition, 88(6), 1543-1551.

Banggo, P. N.A. (2017). Hubungan pengetahuan ibu tentang asi eksklusif dengan praktik pemberian asi eksklusif di Rumah Sakit Umum Dewi Sartika Kendari Tahun 2017 (Doctoral dissertation, Poltekkes Kemenkes Kendari).

Dinas kesehatan Kota Bandar Lampung, (2019).Cakupan Pemberian ASI Ekskluisif. Diakses dari https://erenggar.kemkes.go.id/file2018/eperformance/1-129006-2tahunan-984.docx
Harsanti, $\quad Y_{.}, \quad$ \& Kusumastuti, A. C. (2013). Hubungan pemberian ASI Eksklusif dengan Penurunan Persen Lemak Tubuh Ibu Menyusui (Doctoral dissertation, Diponegoro University).

Janney, C. A., Zhang, D., \& Sowers, M. (1997). Lactation and weight retention. The American journal of clinical nutrition, 66(5), 1116-1124.

Kementrian Kesehatan Republik lindonesia, (2015). Cakupan Pemberian ASI Ekskluisif. Diakses dari https://www.kemkes.go.id/download.php?file=d ownload/pusdatin/infodatin/infodatin-asi.pdf

Kementrian Kesehatan Republik Indonesia,( 2019). Cakupan ASI dan Inisiasi Menyusui Dini. Diakses dari https://pusdatin.kemkes.go.id/download.php?fil $\underline{e=\text { download/pusdatin/infodatin/infodatin-asi.pdf }}$

Kementrian Kesehatan Republik Indonesia. 2017).Cakupan ASI danInisiasiMenyusuiDini. Diakses dari https://pusdatin.kemkes.go.id/download.php?fil e=download/pusdatin/infodatin/infodatin-asi.pdf

Kristiyanti, F. N. A.. (2013). Hubungan pemberian ASI eksklusif dengan penurunan berat badan ibu menyusui (Doctoral dissertation, Diponegoro University).

Margawati, L. (2010). Perbedaan Penurunan Berat Badan Antara Ibu Yang Menyusui Secara Eksklusif Dan Tidak Eksklusif Selama 4 Bulan Postpartum (Studi Di Rumah Bersalin Nur Hikmah Grobogan) Tahun 2009 (Doctoral dissertation, Universitas Negeri Semarang).

Maryunani, A. (2015). Asuhan ibu nifas dan asuhan ibu menyusui. Bogor: In Media.

Nugroho, A. S. (2011). Peranan kelompok pendukung ibu (kp ibu) dalam program peningkatan capaian asi eksklusif (Studi Deskriptif Kualitatif Mengenai Peran Kelompok Pendukung lbu (KP Ibu) Dalam Program Peningkatan Capaian ASI Eksklusif di Kelurahan Semanggi, Kecamatan Pasar Kli. 
Pengaruh pemberian ASl eksklusif dengan penurunan berat badan pada ibu postpartum yang menjalankan ibadah puasa selama bulan Ramadhan

Padmawati, R., \& Dasuki, D. (2011). Pengaruh Menyusui Terhadap Retensi Berat Badan Postpartum di Puskesmas Wilayah Kecamatan Kesambi Kota Cirebon (Doctoral dissertation, [Yogyakarta]: Universitas Gadjah Mada).

Puspitaningrum, Y. (2013). Perbedaan Penurunan Berat Badan Ibu Postpartum Antara Ibu Yang Memberi Asi, Asi Dan Susu Formula, Serta Susu Formula Di Wilayah Kerja Puskesmas Kartasura Sukoharjo (Doctoral dissertation, Universitas Muhammadiyah Surakarta).

Puswati, D. (2012). Pemberian ASI Eksklusif Dan Penurunan Berat Badan lbu Di Wilayah Kerja Puskesmas Tenayan Raya Pekanbaru. Marwah: Jurnal Perempuan, Agama dan Jender, 11(2), 1-18.
Sayekti, R. (2007). Pengaruh Menyusui Secara Eksklusif Selama 6 Minggu Postpartum Terhadap Penurunan Berat Badan Ibu (Doctoral dissertation, Diponegoro University).

Sipasulta, G. C., Afiyanti, Y., \& Sabri, L. (2010). Analisis Faktor-Faktor yang Berhubungan dengan Penurunan Berat Badan lbu Post Partum. Husada Mahakam, 1(I).

Wilda, I., Sarlis, N., \& Mahera, R. (2018). Hubungan pemberian ASI eksklusif dengan penurunan berat badan ibu menyusui. Jurnal Endurance, 3(3), 611-617. 